Ткачук А. П., кандидат історичних наук, аташе з питань оборони

\title{
ЗБРОЙНІ СИЛИ УКРАЇНИ В ДІЯЛЬНОСТІ ПОЛІТИЧНИХ ПАРТІЙ НЕЗАЛЕЖНОЇ УКРАЇНИ: ДО ІСТОРІОГРАФІЇ ПРОБЛЕМИ
}

\begin{abstract}
Анотація. У науковій статті розглянуто стан висвітлення вітчизняними дослідниками проблеми ставлення українських політичних партій і рухів до процесу становлення та розбудови Збройних сил України як елементу гарантування національної безпеки України. Охарактеризовано низку наукових публікацій щодо військового будівництва в Україні, авторами яких є не лише фахові науковці, але й українські політики - безпосередні учасники розбудови української держави. Проведений історіографічний огляд дає підстави стверджувати, що вплив політичних партій на процес становлення, будівництва та реформування Збройних сил України не був належно висвітлений у вітчизняній історичній науці. Українські дослідники фактично залишили поза увагою комплекс питань щодо ставлення політичних партій до створення Збройних сил України, їхньої структури, реформування армії та розроблення належної нормативно-правової бази для вітчизняного політикуму під час ухвалення управлінських рішень. Фактично поза увагою дослідників залишився вплив ідеології окремих партій на розбудову Збройних сил України. Натомість більшість із праць щодо будівництва української армії в новітній період мають суто інформаційно-фактологічну спрямованість, зазвичай стосуються окремих аспектів історії Збройних сил України. Також звернена увага на те, що задекларована тема розкрита недостатньо, а наявний науковий доробок не є методологічно об'єднаним: поза увагою науковців без практичного вирішення залишились питання розроблення методів, концепцій, закономірностей історичного дослідження окресленої проблеми, класифікації та вивчення впливу окремих політичних сил на сферу військового будівництва загалом та Збройних сил України як ії складник зокрема. Дефіцит системних досліджень місця Збройних сил України як чинника національної безпеки України в діяльності українських політичних партій і рухів несе в собі загрозу ухвалення непрофесійних рішень у сфері гарантування національної безпеки, нормативно-правових документів, соціально-економічних рішень і організаційних заходів, продиктованих суто кон'юнктурними міркуваннями окремих політичних сил. Зроблені висновки про те, що вплив політичних партій на процес становлення, будівництва та реформування Збройних сил України не був належно висвітлений у вітчизняній історичній науці, тому необхідне комплексне історичне узагальнення щодо цієї проблеми в майбутньому.

Ключові слова: історіографія, політичні партії, безпека, ЗСУ, військове будівництво.
\end{abstract}

Постановка проблеми. В умовах окупації Криму та військової агресії проти України з боку Російської Федерації питання формування боєздатних Збройних сил України (далі - 3СУ) посідає одне із провідних місць у політиці нашої держави. Це пов'язане з тим, що саме армія є одним із ключових чинників гарантування національної безпеки й оборони, цілісності державних кордонів та суверенітету. Наявність неврегульованого військового конфлікту на Донбасі на тлі складної соціально-економічної ситуації в державі спонукає вітчизняних політиків у своій діяльності приділяти дедалі більше уваги комплексу безпекових питань. 3 огляду на це, можна без перебільшення стверджувати, що ефективність майбутніх військово-політичних рішень, а отже, і зростання рівня національної безпеки України, перебувають у прямій залежності від рівня ефективності парламентарів та їхнього розуміння процесів військового будівництва.

Аналіз останніх досліджень і публікацій. Упродовж останніх років комплекс питань, що стосуються національної безпеки, привернув до себе увагу великої кількості фахівців із різних галузей наук. Особливе місце серед них належить спеціалістам з історії, політології та права, які у своїх дослідженнях розглядали проблему будівництва української армії та зміцнення національної безпеки України. Варто відзначити вагомий внесок В. Горбуліна, Г. Перепелиці, Б. Левика, О. Покотила, Є. Марчука, В. Лазоркіна, А. Папікяна, А. Лопати, В. Гречанінова, О. Пулими й інших вітчизняних науковців. Проте, поряд із процесом становлення ЗСУ, їх будівництва та реформування в незалежній Україні, мало хто з дослідників звертав свою увагу на взаємозалежність між військовим будівництвом і перебігом політичного життя державі. Як наслідок, у сучасній українській історіографії немає цілісних праць, що стосуються проблеми розвитку ЗСУ у візії та діяльності політичних партій незалежної України.

Метою статті $є$ аналіз та характеристика наявної в українській історіографії наукової літератури, яка прямо чи опосередковано висвітлює місце ЗСУ в діяльності українських політичних партій.

Виклад основного матеріалу дослідження. У своїй більшості вітчизняні дослідники, розглядаючи процеси реформування армії та сектора національної безпеки й оборони України, не акцентували свою увагу на ролі в них окремих політичних сил. У кращому разі зазначалося, що рівень розвитку ЗСУ перебуває в залежності від політичної ситуації в державі та від політичного вектора, який реалізовує влада країни на міжнародній арені. Водночас сама історія становлення та розбудови ЗСУ висвітлена в монографіях, статтях, публікаціях у засобах масової інформації. Авторами таких наукових студій були не тільки фахові історики, але й політичні діячі, що прямо чи опосередковано були пов'язані з розбудовою ЗСУ. 
У низці наукових досліджень розглянуто процес становлення української армії саме в контексті державотворчих процесів, що мали місце в Україні на початку 1990-х рр. Можна погодитись з авторами праці «Військове будівництво в Україні у XX столітті: історичний нарис, портрети», які, окреслюючи передумови для створення ЗСУ, зазначали, що відновлення української незалежності розпочалося з утворення та розбудови армії [1]. Важливу роль у цьому процесі відіграв український політикум, який від початку обрав тактику запобігання війнам і попередження військових конфліктів [2].

Однією з перших спроб розглянути процес будівництва ЗСУ можна вважати колективну працю «Історія українського війська, 1917-1995» [3], яка містить системний аналіз практичного втілення в життя ідеї про власну армію в суверенній незалежній Україні. Системно підійшов до висвітлення передумов створення ЗСУ в 1991-1995 pр. історик Б. Якимович [4], який виокремив формування ЗСУ в окрему складову частину націєтворчого піднесення населення України на початку 1990-х рр. Науковець приділив окрему увагу висвітленню зовнішньополітичного тиску, який відчував український політикум під час будівництва ЗСУ. Натомість дослідник А. Папікян вказував на те, що станом на першу половину 1990-х рр. ЗСУ стали повноцінною складовою частиною інституту держави, а не озброєними військовими формуваннями [5]. Тут науковець звертав увагу передусім на наявність необхідного правового підгрунтя для створення ЗСУ, а також політичні обставини ухвалення першої Воєнної доктрини незалежної України. Водночас А. Папікян аргументовано засвідчив провідну роль українського політикуму у процесі формування національної армії України. Ще один український історик П. Скиба [6] акцентував увагу на негативному впливі різного роду чинників на процес закріплення ролі армії в системі гарантування національної безпеки. Зокрема, він вказував на наявність суперечностей у законодавстві щодо становлення та будівництва ЗСУ, які ігнорувалися владою, однак потребували врегулювання. На пряму залежність між радикальним військовим реформуванням і перебігом системної трансформації суспільства вказував В. Чорний [7]. У комплексних та грунтовних дослідженнях українського академіка В. Литвина крізь призму діяльності окремих політичних особистостей деталізовано відображене місце українських політичних сил у процесі ухвалення загальнодержавних рішень, зокрема й тих, що стосувалися питань державної безпеки [8]. Дослідник здійснив глибокий політичний аналіз і дав об'єктивну оцінку політичної історії України, розкривши водночас зміст внутрішньопартійних суперечок, що існували на початку незалежної України $[9 ; 10]$.

У контексті українського державотворення розвиток ЗСУ розглядав один із співзасновників Спілки офіцерів України В. Лазоркін, який розкрив широкому загалу низку невідомих подробиць історії створення українського війська. На основі власного досвіду дослідник описав небезпеку участі у військово-патріотичному русі в Українській Радянській Соціалістичній Республіці наприкінці 1980-х рp. [11]. В. Лазоркін стверджував, що ключову вагу у формуванні українського війська відіграли діячі створеного у Львові громадського Комітету за відродження Української Національної Армії, а також Спілка офіщерів України [12]. Про діяльність Львівської обласної організації Спілки офіцерів України на зламі 1990-х рр. писав військовий історик Д. Бучко [13]. Окремі дослідження про роль
Спілки офіцерів України у процесі формування ЗСУ опублікували А. Русначенко [14], М. Василькевич [15], В. Мартиросян [16] та інші.

Однією 3 найбільш вдалих комплексних публікацій на тему військового будівництва в Україні стала робота київського дослідника Г. Темка, який у 1996 р. розглянув проблеми та перспективи будівництва ЗСУ в нових політичних умовах. Дослідник вказував на правильність тактики українського парламенту, що полягала у створенні механізму захисту нової державності передусім зі створення нормативно-правової бази для діяльності ЗСУ. Також науковець наполягав на необхідності законодавчого врегулювання процесів скорочення ЗСУ, їх технічного переоснащення, розвитку ракетно-космічного напряму, налагодження широких міжнародних військово-політичних контактів, зокрема 3 Росією, поділу радянської військової спадщини. Г. Темко наголошував, що хоча армія не $є$ суб'єктом політики та перебуває поза політичною боротьбою, однак для неї не можуть бути чужими певні риси та напрями партійної боротьби. Саме тому він наполягав на впровадженні національно-історичних традицій у систему військово-патріотичної освіти у ЗСУ [17].

Український військовий дослідник О. Покотило у своій праці показав об'єктивні умови формування української армії, визначив внесок військових, наукових і науково-дослідних центрів у розроблення тематики створення ЗСУ. Науковець встановив повноту та достовірність висвітлення в історіографії законодавчих і нормативних актів, які забезпечили формування армії незалежної держави. О. Покотило також виокремив пріоритетні теми, які були найбільш опрацьовані в українській історіографії створення армії, визначив теми, які потребували подальшого дослідження та стосувалися формування і реформування структури українського війська [18]. Інформативні дані для розуміння ставлення українського суспільства до процесів державотворення і будівництва війська містяться в дослідженнях А. Зоткіна, В. Небоженка, Н. Паніної, Л. Шангіної, Ю. Якименка.

Вітчизняні дослідники ретельно відстежували зростання ролі політичних партій у процесах формування держави та іiі демократичного устрою, їхню боротьбу щодо перспектив майбутнього політичного розвитку держави. Вони також приділили значну увагу дослідженням впливу політичних партій на державотворчі процеси та розвиток окремих компонентів державності. Колосальний внесок у дослідження воєнної організації держави зробив український науковець та політик В. Горбулін, який став одним з авторів Концепції національної безпеки і оборони України, Державної програми будівництва і розвитку ЗСУ, а також інших важливих документів із будівництва та розвитку держави. В. Горбуліним були опубліковані численні наукові праці, що порушували проблеми зміцнення системи національної безпеки, розвитку ЗСУ, входження України до систем колективної безпеки. Наукові студії В. Горбуліна стосувались питань національної безпеки [19], оборонної політики держави [20], взаємодії політичного істеблішменту у сфері посилення національної безпеки країни. Разом з іншими українськими фахівцями О. Литвиненком і О. Бєловим В. Горбулін свого часу зауважив, що вітчизняні політичні еліти й істеблішмент Російської Федерації становитимуть собою небезпеку для України. Для вирішення цієї проблеми пропонувалося будівництво власної армії, яка 6 відповідала вимогам часу та могла дати гідну 
відсіч на будь-які виклики [21]. Дослідник неодноразово критикував вітчизняну політичну еліту за ігнорування життєво важливих державницьких питань, зокрема у сфері військового будівництва.

Ще одним безпосереднім учасником процесу розроблення концепцій військової реформи в Україні є український політик А. Гриценко, який свого часу працював як у виконавчій, так і в законодавчій владі. Йому належать чимало аналітичних розвідок і грунтовних досліджень широкого спектра питань державного будівництва. В одній із праць А. Гриценко здійснив аналіз воєнних аспектів програмних документів політичних партій, що брали участь у парламентських виборах 2002 р. Науковцем було виокремлено та згруповано пріоритети та заплановані заходи у сфері воєнної безпеки, які мали намір реалізовувати певні політичні сили в разі потрапляння в парламент. Виходячи із зібраних даних, А. Гриценко зробив прогноз щодо можливих законодавчих ініціатив майбутнього парламенту у сфері розбудови військової організації держави та військового будівництва [22].

Стратегічний характер національних інтересів країни, особливості їх формування під час підготовки й ухвалення Концепції національної безпеки та Воєнної доктрини України показав у своїй праці Л. Артюшин [23], який звернув увагу на складні зовнішньополітичні обставини ухвалення згаданих документів. Комплексний аналіз сутності воєнної могутності України й особливості впливу на цей процес зовнішніх чинників здійснив також історик В. Смолянюк [24], який висловив переконання, що Україна була змушена адаптуватися до військово-силових реалій геополітики, що влада України на початку 1990-х рр. під час створення ЗСУ виходила з доцільності існування невеликої за чисельністю і структурою та сучасно озброєної армії [25]. Українські дослідники часто зіставляли наявну концепцію чи стратегію будівництва ЗСУ 3 реальним станом нормативно-правової бази системи національної безпеки. Такий підхід часто змушував їх до характеристики візії політичних партій та рухів щодо перспектив розвитку системи нацбезпеки та місця в ній Збройних сил. Серед таких праць варто відзначити наукові студії В. Мунтіяна [26], В. Бринцева [27], В. Бегми [28] та ін.

Деякі з українських дослідників уже робили спроби аналізу програмних документів українських політичних партій на предмет висвітлення концепції національної безпеки й оборони України. Зокрема, науковець Б. Левик провів критично-порівняльний аналіз партійних програм у 1992-2009рр. щодо проблем національної безпеки й оборони України. За його словами, у досліджуваний період український політикум не мав єдиного стратегічного підходу щодо гарантування національної безпеки. Науковець вказував на можливість зменшення рівня загроз для нацбезпеки за умови консолідації політичної еліти, суспільства, стабілізації внутрішньополітичної ситуації, ефективної реалізації стратегічно узгодженого зовнішньополітичного курсу та консолідації нації [29]. Взаємозв'язок між соціальним розвитком держави та іiі національною безпекою і станом боєздатності армії простежували у своїх дослідженнях О. Панфілов [30], О. Корнієвський [31, 32], Г. Ситник [33], М. Требін [34], В. Богайчук [35], С. Пирожков. Дослідники погоджувались із тим, що саме політичні партії відображали основні запити суспільства щодо майбутнього розвитку силового блоку держави. Щоправда, більшість із зазначених досліджень в основному мають інформаційно-фактологічний характер, отже, лише ілюструють окремі аспекти процесу військового будівництва, залишаючи поза увагою комплекс питань, що стосуються участі політичних партій у цьому процесі.

Серед наукових напрацювань цієї тематичної ніші значне зацікавлення викликають публікації, що стосуються діяльності ЗСУ поза межами України. Зокрема, дослідник I. Поліщук зумів дослідити та показати особливості загальноєвропейських процесів із підтримки миру, місце в них українських військових [36]. Схожою за тематикою є робота В. Венгера [37]. Нормативно-правову базу миротворчої діяльності ЗСУ аналізував А. Панюк [38]. Про необхідність формування європейської системи безпеки із залученням до цього процесу України писав у своїх статтях В. Радецький [39; 40]. На думку О. Луника, саме активна миротворча діяльність ЗСУ стала запорукою входження України до світової системи збереження миру. Щоправда, науковець залишив поза увагою соціально-економічні обставини підготовки миротворчих контингентів і участі в цих процесах центральних органів державної влади [41]. Ще один український історик О. Пулим розглядав участь ЗСУ в миротворчих операціях під егідою Організації Об'єднаних Націй (далі OОН) як складову частину процесу інтеграції з НАТО, однак науковець фактично залишив поза своєю увагою чинники, які спонукали українську політичну еліту ініціювати участь наших військових в операціях поза межами України [42]. У своїх працях дослідник В. Гречанінов через аналіз передусім політичної ситуації у світі намагався показати місце України в системі міжнародних відносин, а також спрогнозувати перспективу розвитку $[43 ; 44]$.

У контексті розбудови української армії Г. Перепелиця звертав увагу на місце України в архітектурі європейської безпеки [45], процеси ядерного роззброєння та реформування ЗСУ [46], їхні передумови та перспективи, перспективи співробітництва України та НАТО [47], миротворчу діяльність 3СУ, проблеми функціонування військових формувань у відносинах України iз сусідніми державами [48], досвід європейських країн щодо парламентського контролю над Збройними силами [49]. Інший український дослідник О. Бодрук переконував, що Україні варто активізувати свою діяльність у напрямі входження до європейської системи безпеки, розвивати відносини з НАТО, оскільки ООН не може ефективно реагувати на новітні загрози [50]. Він вбачав загрозу для національної безпеки в неспроможності ЗСУ належно виконувати свої функції через політизацію силових структур та політичну кризу, що могла розвиватись паралельно з тотальним зменшенням фінансування української армії. Окрім того, деякі науковці розглядали можливість створення недержавного забезпечення системи національної безпеки й оборони, порушували питання надійності державного контролю й управління системою національної безпеки, рівня єдності політичної еліти в окресленні національних інтересів, цілісності концепції національної безпеки в політичній думці, обгрунтовували ключові поняття і категорії. Серед вітчизняних науковців, які зробили найбільший внесок у дослідження процесу будівництва системи національної безпеки України та розбудови іiі ЗСУ, особливо вирізняється науковий доробок таких дослідників, як: О. Власюк [51], О. Затинайко, В. Абрамов, А. Курас [52], А. Кузьменко, В. Головко [53], Б. Парахонський, Г. Ситник, М. Требін [54], В. Антонов [55] та ін. 
Висновки. Станом натепер в українській історичній науці проблема впливу політичних партій на процес розбудови ЗСУ залишається недостатньо розкритою. 3 великою долею впевненості можна констатувати, що процес будівництва та розвитку ЗСУ у візії українських політичних партій нині ще не став предметом всебічного науково-практичного вивчення, адже наявні наукові праці є методологічно необ'єднаними, не мають цілісної наукової теорії, а самі дослідники зосереджують увагу здебільшого на окремих проблемах військового будівництва в Україні. Досі немає всебічного комплексного аналізу нормативно-правової бази сектора безпеки й оборони, яка стала основою для ухвалення управлінських рішень вищими органами державної влади, а також представленими у Верховній Раді України політичними силами під час розроблення й ухвалення законодавчих ініціатив щодо будівництва та реформування ЗСУ, ї матеріально-технічного забезпечення, соціального захисту військовослужбовців i членів їхніх сімей. Поза увагою вітчизняних науковців досі залишається тема впливу ідеології окремих політичних сил на процес військового будівництва в Україні. Здебільшого наявні наукові праці мають суто інформаційно-фактологічну спрямованість, зазвичай стосуються окремих подій у розвитку українського війська. Такий стан речей несе в собі загрозу впливу суто кон'юнктурних міркувань на державну політику в галузі безпеки. Практична відсутність концептуальних досліджень, автори яких простежують взаємозв'язок між розвитком політичних партій України та процесами становлення, будівництва і реформування ЗСУ, дає підстави стверджувати, що ця тема не була висвітлена у вітчизняній історичній науці, а вже наявний науковий доробок $€$ явно недостатнім і потребує поповнення в майбутньому.

\section{Jimepamypa:}

1. Військове будівництво в Україні у ХХ столітті : історичний нарис, портрети / за заг. ред. О. Кузьмука. Київ : Видавничий дім «Ін Юре», 2001. 448 c.

2. Декларація про державний суверенітет Украни. Biдомості Верховної Ради Української Радянської Соиіалістичної Республіки. 1990. № 31. Ст. 429. URL: https://zakon.rada.gov.ua/laws/show/55-12.

3. Історія українського війська, 1917-1995 / В. Гриневич та ін. ; упоряд., передм. Я. Дашкевич. Львів : Світ, 1996. 837 с.

4. Якимович Б. Збройні сили України. Нарис історії. Львів : Інститут українознавства ім. Івана Крип'якевича НАН України, 1996. 360 с.

5. Папікян А. Збройні сили України двадцятого століття. Львів : КП «Видавництво «Кобзар»», 1999. 308 с.

6. Скиба П. «Будівництво і розвиток» Збройних сил України, або як пройти шлях від воєнної організації держави до з'єднання. Славута, 2013. 268 с.

7. Чорний В. Військова організація України: становлення та перспективи розвитку : монографія ; Нац. акад. оборони України. Ніжин : Аспект-Поліграф, 2009. 368 с.

8. Литвин В. Політична арена України: Дійові особи та виконавці. Київ : Абрис, 1994. 495 с.

9. Литвин В. Україна на межі тисячоліть (1991-2000рр.) / за заг. ред. В. Смолія. НАН України. Інститут історії України. Київ : Альтернативи, 2000. 260 c

10. Литвин В. Украина: политика, политики, власть: на фоне политического портрета Л. Кравчука. Киев, 1997. 335 с.

11. Лазоркін В. Львів. 1989-1991 роки. Шануймося, панове офічери. Київ : Варта, 2001. С. 121-183.

12. Лазоркін В. Деякі сторінки з історії творення Збройних сил України. Кримська Світлиия. 2016. № 7. URL: http://svitlytsia.crimea.ua/ index.php?section $=$ article $\&$ artID $=16657$.
13. Бучко Д. Роль Спілки офіцерів України на етапі формування основ Збройних сил України: регіональні аспекти. Військово-науковий вісник. 2011. Вип. 16. С. 3-11.

14. Русначенко А. На шляху до національної армії. Утворення Спілки офіцерів України. Шануймося, панове офіцери. Київ : Варта, 2001. C. 7-44.

15. Василькевич М., Боренько С. Спілка офіцерів України Львівської області - 15 років від часу заснування. За вільну Україну. 2006.

16. Мартиросян В. Спілка Офіцерів України. Шануймося, панове офiцери. Київ : Варта, 2001. С. 183-197.

17. Темко Г. Будівництво Збройних сил України: проблеми i перспективи. Украӥнський історичний журнал. 1996. № 4. C. $13-23$.

18. Покотило О. Створення Збройних сил України: історіографія : автореф. дис. ... канд. іст. наук: 20.02.22. Київ, 2012. 20 с.

19. Горбулін В., Качинський А. Засади національної безпеки України. Київ : Інтертехнологія, 2009. 270 с.

20. Оборонна політика України на початку XXI ст. / В. Горбулін та ін. Київ : Інтертехнологія, 2009. 103 с.

21. Горбулін В., Бєлов О., Литвиненко О. Національна безпека: порядок денний для України. Київ : Стилос, 2009. 126 с.

22. Гриценко А. Проблеми воєнної політики у програмах політичних партій. Національна безпека і оборона. 2002. № 1. С. 8-23.

23. Артюшин Л., Костенко Г. Теоретичні аспекти стратегії воєнної безпеки суспільства і держави. Нац. ун-т внутр. справ. Харків, 2003. $175 \mathrm{c}$

24. Смолянюк В. Військова могутність України : теоретико-методологічні засади формування і розвитку (політологічний аналіз досвіду 1990-х рр.). Київ ; Ірпінь : ВТФ «Перун», 2000. 466 с.

25. Смолянюк В. Військова реформа в Україні: Необхідність? Вимушеність? Приреченість? Людина і політика. 2000. № 5. С. 27-30.

26. Воєнна політика України: проблеми і пріоритети / В. Мунтіян та ін. Київ : НІСД, 1996. 87 с.

27. Збройні сили незалежної України. Перші 10 років (1991-2001)/ за ред. В. Бринцева. Київ : НАОУ, 2006. 378 с.

28. Основи державного управління процесами формування і реалізації оборонної політики України / В. Бегма та ін. Київ : Євроатлантикінформ, 2007. $168 \mathrm{c}$.

29. Левик Б. Розвиток концепції національної безпеки і оборони України в програмних документах українських політичних партій в період 1992-2009рр. (воєнно-історичний аспект) : автореф. дис. ... канд. іст. наук: 20.02.22. Львів, 2010. 17 с.

30. Панфілов О. Політичний фактор як складова воєнно-силових можливостей держави. Наукові записки Харківіського університету Повітряних Сил. Серія «Соціальна філософія, психологія». 2007. Вип. 3. С. $105-111$.

31. Корнієвський О. Ефективність взаємовідносин держави і громадянського суспільства як чинник забезпечення національної безпеки. Стратегічна панорама. Київ : НІПМБ, 2009. № 1. С. $158-165$.

32. Корнієвський О. Громадські об’єднання як суб’єкт політики національної безпеки: до постановки проблеми. Стратегічні пріоритети. Київ : НІСД, 2009. № 1. С. 43-50.

33. Ситник Г. Державне управління національною безпекою України. Київ : Вид-во НАДУ, 2004. 408 с.

34. Требін М. Армія та суспільство : соціально-філософський аналіз взаємодії в умовах трансформації. Харків : Вид-ий дім «Інжек», 2004. $404 \mathrm{c}$.

35. Богайчук В., Мулява В. Основні чинники військового будівництва в контексті національної безпеки України. Держава $i$ право. Юридичні і політичні науки : збірник наукових праць. 2007. Вип. 36. С. 571-576.

36. Поліщук І. Миротворча діяльність Збройних сил України: досвід, проблеми, перспективи. Київ, 1998. Вип. 2. С. 197-213. 
37. Венгер В. Основні напрями міжнародного військового співробітництва Збройних сил України (минуле, сучасність і майбутнє). Військо Украӥни. 1999. С. 5-6.

38. Панюк А. Збройні сили України в системі міжнародних зв'язків. Держава і армія : вісник. Львів : Держ. ун-т «Львівська політехніка», 1999. № 377. С. 206-214.

39. Радецький В. Початок року: будівництво, навчання, миротворство. Народна армія. 1994. 25 лютого.

40. Радецький В. Вступ до Альянсу як вирішення складової національної безпеки україни. Військо Украӥни. 2006. № 1. С. 10-12.

41. Луник О. Формування системи залучення Збройних сил України до врегулювання воєнних конфліктів (1992-2002 pp.) : дис. ... канд. істор. наук: 20.02.22. Київ, 2003. 238 с. URL: http://irbis-nbuv. gov.ua/cgi-bin/irbis nbuv/cgiirbis 64.exe.

42. Пулим О. Збройні сили України як фактор створення та забезпечення існування системи колективної безпеки у Європі : дис. ... канд. істор. наук: 20.02.22. Львів, 2001. 179 с.

43. Гречанінов В. Відсутність знань, що породжує міфи. Атлантична панорама. 2006. № 2. С. 23-25.

44. Гречанінов В. «Партнерство заради миру» як загальноєвропейська перспектива. Урядовий кур'єрю 1995. 25 травня.

45. Перепелиця Г. Без'ядерний статус і національна безпека України. Київ : НІСД, 1998. 108 с.

46. Воєнна безпека України на межі тисячоліть : монографія / Г. Перепелиця та ін. Київ : Стилос, 2002. 384 с.

47. Україна на шляху до НАТО: через радикальні реформи до набуття членства / О. Дергачов та ін. ; ред. Г. Перепелиця. Київ : Видавничий дім «Стилос», 2004. 407 с.

48. Миротворча діяльність України: кооперація з НАТО та іншими структурами європейської безпеки / Г. Перепелиця та ін. ; підгот. Г. Перепелиця ; НІСД при Адміністрації Президента України ; Королівський ін-т міжнародних справ. Київ : Стилос, 2002. 313 с.

49. Парламентський контроль над збройними силами: досвід європейських країн : монографія /. Г. Перепелиця (кер. авт. кол.) та ін. Київ : Стилос, 2002. 552 с.

50. Бодрук О. Структури воєнної безпеки: національний та міжнародний аспекти : монографія. Київ : НІПМБ, 2001. 300 с

51. Власюк О. Національна безпека України: еволюція проблем внутрішньої політики : вибрані наукові праці. Київ : НІСД, 2016.527 c

52. Курас А. Національна безпека України: військово-політичні парадигми. Наукові записки Інституту політичних і етнонаціональних досліджень ім. І.Ф. Кураса. 2014. Вип. 2. С. 230-240.

53. Оборонно-промислова політика України: можливості застосування досвіду Вишеградських країн / В. Головко й ін. Донецьк : ДФ НІСД, 2008. 292 с.

54. Абрамов В., Ситник Г., Смолянюк В. Глобальна та національна безпека / за заг. ред. Г. Ситника. Київ : НАДУ при Президентові України, 2016. 784 с.
55. Антонов В. Поняття та зміст національної безпеки. Правова держава : щорічник наукових праць. 2008. Вип. 19. С. 153-161.

Tkachuk A. Armed Forces of Ukraine in the activities of independent political parties: a historiography of the issue

Summary. The article deals with the state of highlighting by domestic researchers of the attitude of Ukrainian parties and movements to the formation and development of the Armed Forces of Ukraine as an element of ensuring national security of Ukraine. Several scientific publications on military construction in Ukraine have been characterized, not only by professional scientists but also by Ukrainian politicians direct participants in the development of the Ukrainian state. The conducted historiographical review gives reasons to assert that the influence of political parties on the formation, construction, and reformation of the Armed Forces did not receive satisfactory coverage in national historical science. Ukrainian researchers actually left unattended complex of issues on the attitude of political parties to the creation of the Armed Forces, their structure, army reform, and the development of a proper regulatory framework for the domestic political decision-making process. In fact, the influence of the ideology of individual parties on the development of the Armed Forces remained completely out of the researchers' view. Instead, most of the works on building the Ukrainian army in the recent period are purely factual and generally refer to certain aspects of the history of the Armed Forces. Attention is also drawn to the fact that the research level of the mentioned topic is not disclosed enough and that the available scientific background is not methodologically integrated. The questions of methods developing, concepts, patterns of a historical study of the outlined problem, classification, and study of the influence of individual political forces on the sphere of military construction in general and the Armed Forces, as its component, in particular, remained practically without scientists' attention. The lack of systematic research on the place of the Armed Forces as a factor of national security of Ukraine in the activities of Ukrainian political parties and movements poses a threat to the approval of unprofessional decisions in the national security, the adoption of regulatory documents, the approval of socio-economic decisions and organizational measures ordered solely by selfish considerations of individual political forces. It is concluded that the influence of political parties on the process of formation, construction, and reformation of the Armed Forces has not been appropriately covered in national historical science, and therefore requires a comprehensive historical generalization of this problem in the future.

Key words: historiography, political parties, security, Armed Forces, military construction. 